ISSN 1678-3921

Journal homepage: www.embrapa.br/pab

For manuscript submission and journal contents, access: www.scielo.br/pab

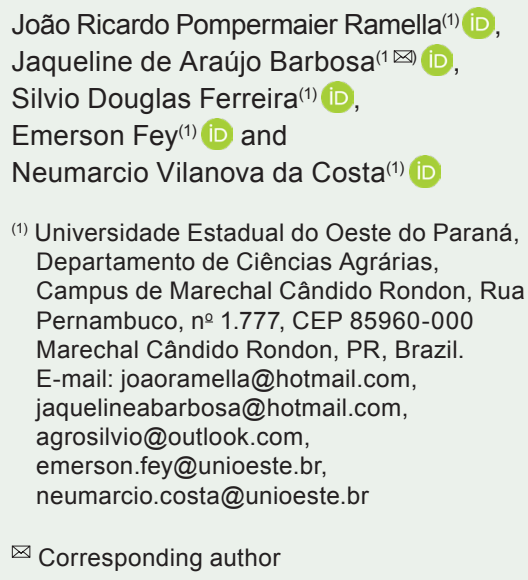

João Ricardo Pompermaier Ramella(1) (iD), Jaqueline de Araújo Barbosa ${ }^{(1 凶)(D)}$, Silvio Douglas Ferreira(1) (iD, Emerson Fey ${ }^{(1)}$ (iD and Neumarcio Vilanova da Costa(1) (iD)

(1) Universidade Estadual do Oeste do Paraná, Departamento de Ciências Agrárias, Campus de Marechal Cândido Rondon, Rua Pernambuco, № 1.777, CEP 85960-000 Marechal Cândido Rondon, PR, Brazil. E-mail: joaoramella@hotmail.com, jaquelineabarbosa@hotmail.com agrosilvio@outlook.com, emerson.fey@unioeste.br. neumarcio.costa@unioeste.br

$\bowtie$ Corresponding author

Received

December 24, 2019

Accepted

August 20, 2020

How to cite

RAMELLA, J.R.P.; BARBOSA, J. de A.;

FERREIRA, S.D.; FEY, E.; COSTA, N.V. da. Weed interference on nutrient accumulation in the leaves of cassava under no-tillage or conventional tillage. Pesquisa Agropecuária Brasileira, v.55, e01750, 2020. DOI: https://doi. org/10.1590/S1678-3921.pab2020.v55.01750.

\section{Weed interference on nutrient accumulation in the leaves of cassava under no-tillage or conventional tillage}

\begin{abstract}
The objective of this work was to evaluate the effect of weed competition on the accumulation of nitrogen and phosphorus in the leaves and on the dry weight of the roots of cassava (Manihot esculenta) in the conventional and no-tillage systems, in two crop cycles. The experiments were carried out in a randomized complete block design, with split-split plots and four replicates. The plots consisted of conventional tillage or no-tillage; the split plots, of the competition or not with weeds; and the split-split plots, of the evaluation periods $(0,25,50,75,100,125,150,175,200$, and 225 days after planting/pruning). In the first cycle, weed competition reduced the accumulation of nitrogen in 82.6 and $81.3 \%$ and of phosphorus in 65.7 and $85.3 \%$ under conventional tillage and no-tillage, respectively. In the second cycle, the reductions in the accumulation of nitrogen were of 41.1 and $52.4 \%$ and of phosphorus of 44.1 and $52.6 \%$, in conventional tillage and no-tillage, respectively. The root dry weight of cassava grown with weed competition showed reductions of 15.8 and $11.2 \%$ under conventional tillage and notillage, respectively, only in the second cycle. Weed competition reduces the accumulation of nitrogen and phosphorus in the leaves of cassava in the conventional and no-tillage systems in both crop cycles, but reduces the dry matter of cassava roots only in the second cycle.
\end{abstract}

Index terms: Manihot esculenta, nitrogen, phosphorus, root dry weight.

\section{Interferência de plantas daninhas no acúmulo de nutrientes em folhas de mandioca sob plantio direto ou plantio convencional}

Resumo - O objetivo deste trabalho foi avaliar o efeito da competição de plantas daninhas sobre o acúmulo de nitrogênio e fósforo nas folhas e sobre a massa seca das raízes de mandioca (Manihot esculenta), nos sistemas convencional e direto, em dois ciclos de cultivo. Os experimentos foram realizados em delineamento de blocos ao acaso, com parcelas subsubdivididas e quatro repetições. As parcelas consistiram do plantio convencional ou do plantio direto; as subparcelas, da competição ou não com plantas daninhas; e as subsubparcelas, dos períodos de avaliação $(0,25,50,75,100,125,150$, 175, 200 e 225 dias após o plantio/poda). No primeiro ciclo, a competição com plantas daninhas reduziu o acúmulo de nitrogênio em 82,6 e 81,3\% e o de fósforo em 65,7 e $85,3 \%$, no plantio convencional e no plantio direto, respectivamente. No segundo ciclo, as reduções no acúmulo de nitrogênio foram de 41,1 e $52,4 \%$ e, no de fósforo, de 44,1 e $52,6 \%$, no plantio convencional e no plantio direto, respectivamente. A massa seca das raízes de mandioca cultivada sob competição de plantas daninhas apresentou reduções 
de 15,8 e $11,2 \%$ no plantio convencional e no plantio direto, respectivamente, apenas no segundo ciclo. A competição de plantas daninhas reduz o acúmulo de nitrogênio e fósforo nas folhas de mandioca, nos sistemas convencional e plantio direto, em ambos os ciclos de cultivo, mas reduz a matéria seca das raízes de mandioca apenas no segundo ciclo.

Termos para indexação: Manihot esculenta, nitrogênio, fósforo, massa seca de raiz.

\section{Introduction}

Cassava (Manihot esculenta Crantz) is a staple food for around 800 million people worldwide (FAO, 2019). Due to its rustic characteristics and easy adaptation to different climates and soil conditions, the species has been cultivated by farmers in more than 100 tropical and subtropical countries in Africa, Asia, and Latin America (Latif \& Müller, 2015; FAO, 2019).

In Brazil, most of the cassava production occurs in the Southern region and is aimed at the starch and flour industry. The varieties used in this industry can be harvested either 10 to 12 months (first cycle) or 20 to 22 months (second cycle) after planting, depending on the price of the ton of roots at the time (Takahashi \& Gonçalo, 2001). However, despite having a high productive potential and economic importance, cassava crops are usually grown in regions with low fertility soils and with low investments in fertilizers and other agricultural inputs (Guimarães et al., 2019). This practice, together with the slow initial growth of the crop, leaves the soil uncovered and allows the emergence of weeds (Biffe et al., 2010; Silva et al., 2012).

In extreme cases, weeds can limit the development and productivity of cassava crops by up to $100 \%$ (Johanns \& Contiero, 2006). This happens because, even though cassava positively responds to the amount of nutrients present in the soil, weeds absorb them faster, reducing the crop's productive potential. In crops such as soybean [Glycine $\max$ (L.) Merr.], for example, weed community interference reduced nutrient accumulation by $85 \%$ (Carvalho et al., 2010). Despite these results, knowledge about nutrient accumulation in cassava plants under competition with weeds is still scarce.

Although plant nutrient levels can be increased by improving soil fertility, in general, cassava producers do not apply fertilizers during the crop cycle. However, cassava varieties respond positively to mineral fertilization, with a reported productivity greater than $30 \mathrm{Mg} \mathrm{ha}^{-1}$ (Munyahali et al., 2017). Nitrogen application, for example, can increase cassava production by approximately $17.03 \mathrm{Mg} \mathrm{ha}^{-1}$, compared with areas without this type of fertilizer (Kang et al., 2020). Likewise, phosphorus application is extremely important to increase cassava crop yield, considering that Brazilian soils are generally deficient in this nutrient (Pereira et al., 2012). When fertilized with phosphate, rather than with nitrogen and potassium, cassava plants have shown a greater root production (Fidalski, 1999).

The dynamics between the nutrients present in the soil and the weed community are influenced by the soil tillage system (Pereira et al., 2012; Acharya et al., 2019). Cassava crops are usually cultivated in a conventional tillage system with soil turnover. However, conventional cultivation favors the degradation of the physical and chemical structures of the soil, as well as the occurrence of erosion after high and intense rains, besides stimulating the emergence of the weeds present in the seed bank. In this scenario, the no-tillage system is an alternative method of soil conservation that can contribute to the sustainability of cassava crops, being beneficial for recharging soil nutrient stock over time (Gabriel Filho et al., 2000; Figueiredo et al., 2017). Other benefits of no-tillage in the cassava crop were pointed out by Otsubo et al. (2012), who found that growing the IAC 15 cassava cultivar on oat (Avena strigosa Schreb.) straw was a sustainable production alternative that may not even require the use of herbicides for weed control. These results are indicative that the conventional tillage and the no-tillage systems modify the emergence dynamics of weeds and, consequently, their ability to compete with cassava crops for soil nutrients.

The objective of this work was to evaluate the effect of weed competition on the accumulation of nitrogen and phosphorus in the leaves and on the dry weight of the roots of cassava in the conventional and no-tillage systems, in two crop cycles.

\section{Materials and Methods}

The experiments were carried out from September 2014 to June 2015 (first cycle) and from June 2015 to May 2016 (second cycle) in the municipality of 
Entre Rios do Oeste, in the state of Paraná, Brazil

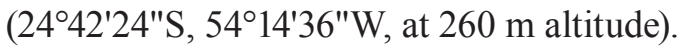

The climate, according to Köppen-Geiger, is of the Cfa type, i.e., subtropical, with average annual rainfall of $1,700 \mathrm{~mm}$ and annual average temperature between 22 and $23^{\circ} \mathrm{C}$ (Alvares et al., 2013). The climatic data collected in the experimental period are shown in Figure 1.

The soil of the study area was classified as a Latossolo Vermelho eutroférrico típico (Santos et al., 2018), i.e., a Rhodic Ferralsol. The soil textural analysis showed $377 \mathrm{~g} \mathrm{~kg}^{-1}$ clay, $551 \mathrm{~g} \mathrm{~kg}^{-1}$ silt, and $72 \mathrm{~g} \mathrm{~kg}^{-1}$ sand, in addition to the following chemical characteristics: $\mathrm{pH}\left(\mathrm{CaCl}_{2}\right)$ 5.95, $0.0 \mathrm{cmol}_{\mathrm{c}} \mathrm{dm}^{-3} \mathrm{Al}^{3+}$, $4.14 \mathrm{cmol}_{\mathrm{c}} \mathrm{dm}^{-3} \mathrm{Ca}^{2+}, 3.67 \mathrm{cmol}_{\mathrm{c}} \mathrm{dm}^{-3} \mathrm{Mg}^{2+}, 31.30 \mathrm{mg}$ $\mathrm{dm}^{-3} \mathrm{P}, 0.88 \mathrm{cmol}_{\mathrm{c}} \mathrm{dm}^{-3} \mathrm{~K}, 6.12 \mathrm{~g} \mathrm{dm}^{-3}$ organic matter, and base saturation of $76.10 \%$. There was no need to perform basic fertilization at planting (Moreira et al., 2017).

For both evaluated cycles, the experiments were set up simultaneously in September 2014. The IAC 90 cassava variety was planted at a spacing of $0.90 \times 0.60 \mathrm{~m}$, using the Bazuca two-row cassava planter (Planti Center, Marialva, PR, Brazil).

In the first cycle, the crop was managed by hand hoeing to avoid weed interference. In the second, the cassava branches were pruned in July 2015, after which the experiment was started. Plant stems were pruned manually with the aid of a machete, being cut at $15 \mathrm{~cm}$ above ground level; all residues were removed from the area.

The experimental design in both experiments was randomized complete blocks with split-split plots and four replicates. The plots consisted of the soil tillage systems (conventional tillage and no-tillage); the split plots, of the competition or not between crop and weed; and the sub-subplots, of the evaluation periods of the cassava plants, which were $0,25,50,75,100$, $125,150,175,200$, and 225 days after planting (DAP) or days after pruning (DAPr). Each split-split plot consisted of four rows spaced at $0.90 \mathrm{~m}$, with $8 \mathrm{~m}$ in length, and total area of $28.8 \mathrm{~m}^{2}$. Weed control in the

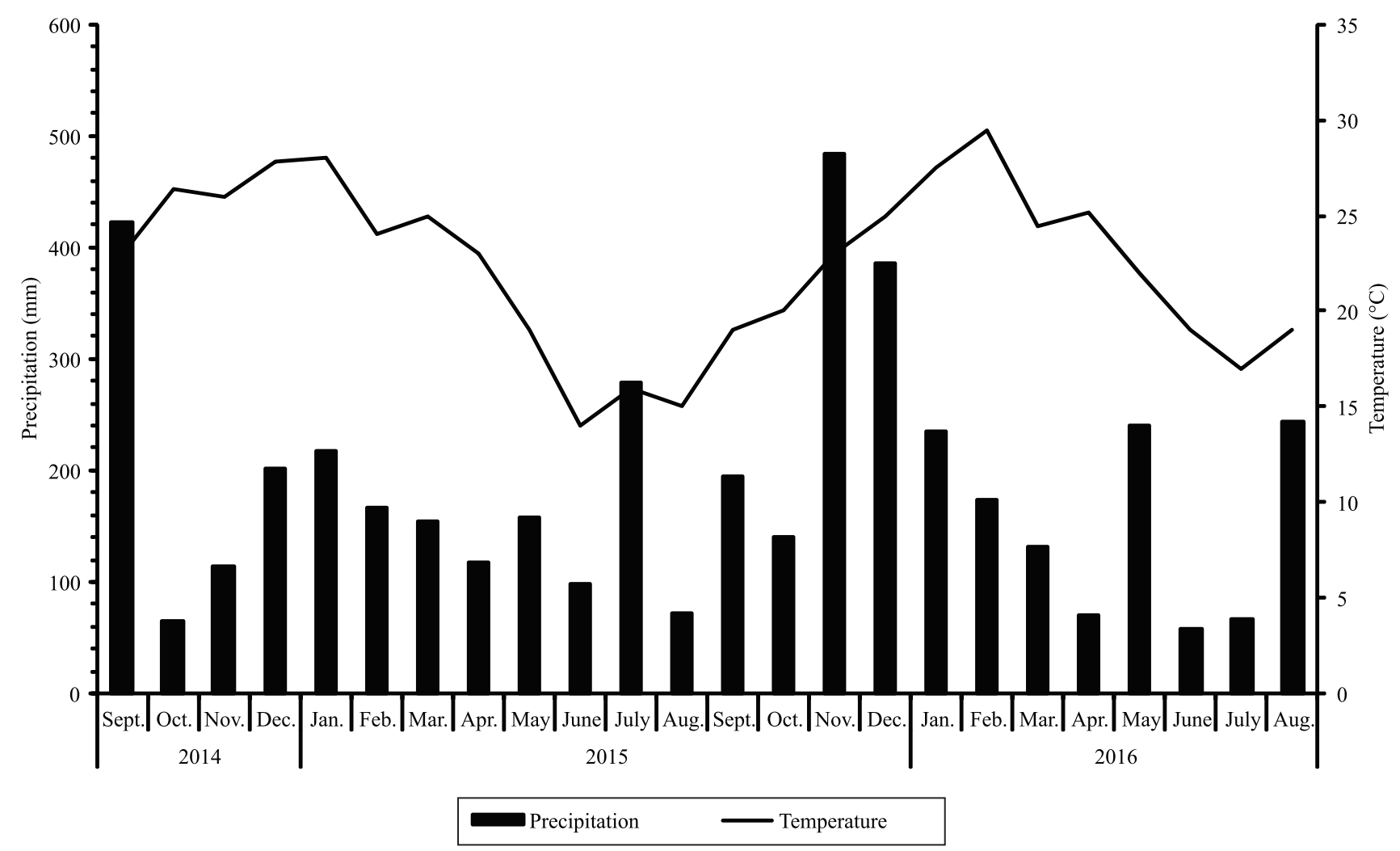

Figure 1. Monthly data on cumulative precipitation and average temperature during the experimental period from 2014 to 2016, in the municipality of Entre Rios do Oeste, in the state of Paraná, Brazil. Data were collected at the weather station of Entre Rios do Oeste. 
sub-subplots without competition was performed by manual weeding.

In the no-tillage system, the experimental area was previously cultivated with soybean (harvest in October/February) and corn (Zea mays L.) (second crop in March/June). In August 2014, 30 days before cassava was planted, the area was desiccated by applying the glyphosate herbicide at a rate of $1,080 \mathrm{~g}$ $\mathrm{ha}^{-1}$ acid equivalent, with the aid of a tractor sprayer, leaving approximately $7.7 \mathrm{Mg} \mathrm{ha}^{-1}$ corn straw on the ground. In the conventional tillage system, turnover was performed with one plowing and two harrowing operations 30 days before cassava planting.

The total biomass of the weed community was estimated at the end of each evaluation period by collecting the weeds present in a $0.25-\mathrm{m}^{2}$ quadrat $(0.5 \times 0.5 \mathrm{~m})$, which was thrown at the center of each sub-subplot. The result was expressed as weed dry weight $\left(\mathrm{Mg} \mathrm{ha}^{-1}\right)$. Weeds were then identified according to data from specialized literature (Lorenzi, 2014).

At the end of each evaluation period, four cassava plants were also collected from the central rows of the sub-subplots - with and without weed competition and taken to the laboratory to determine shoot dry weight and foliar nitrogen and phosphorus contents $\left(\mathrm{g} \mathrm{kg}^{-1}\right)$, following the methodology proposed by Lana et al. (2016). Subsequently, nutrient accumulation was calculated by multiplying shoot dry weight by nutrient content values, which were adjusted to $\mathrm{kg} \mathrm{ha}^{-1}$. In addition, roots were sanitized and taken to a forced-air circulation oven, at $65^{\circ} \mathrm{C}$, until constant dry weight, for the determination of root dry weight yield $\left(\mathrm{Mg} \mathrm{ha}^{-1}\right)$.

The data on the evaluated parameters were subjected to the analysis of variance, at $5 \%$ probability, using the Sisvar, version 5.1, computer software (Ferreira, 2019). The results of the means were subjected to the regression analysis, using the SigmaPlot, version 12.0, software (Systat Software Inc., 2011). The used equations were chosen based on significant models, which were approved in the normality, biological logic, and high coefficient of determination tests.

\section{Results and Discussion}

During the experimental period, 11 and 13 weed species were identified in the no-tillage and conventional tillage systems, respectively (Table 1). The occurrence dynamics of the weed species was different in each system during the cassava crop cycles (Figure 2). Under conventional tillage, maximum weed dry weight accumulation occurred at 159.1 and 155.0 DAP and DAPr in the first and second crop cycles, respectively, that is, 46.6 and 43.3 days before in the tillage system.

These results indicate that the presence of straw in the no-tillage system provided a physical barrier to the emergence of the weed seed bank, particularly damaging positive photoblastic seeds and/or seeds that need alternating temperatures to germinate (Acharya et al., 2019). In this line, Otsubo et al. (2012) concluded that the direct planting of IAC 15 cassava cultivar on oat straw was a sustainable production alternative that did not require the use of herbicides for weed control.

In the first cycle, under conventional tillage and without weed competition, $50 \%$ of the nitrogen absorbed during the crop's full cycle was already accumulated in the leaves at 161.1 DAP. This accumulation was 17.2\% higher than that in the plants grown under no-tillage (Figure 3 A). With weed competition, the cassava plants were stressed and only accumulated $50 \%$ of the nitrogen absorbed during the whole cycle 85 and 76 days later under conventional tillage and no-tillage, respectively.

In the last assessment at 225 DAP, without weed competition, the cassava plants reached maximum foliar nitrogen accumulation in both cultivation systems. However, when grown with weeds, the plants

Table 1. Description of the weeds present in the two crop cycles of cassava (Manihot esculenta) grown under no-tillage (NT) and conventional tillage (CT) from September 2014 to May 2016, in the municipality of Entre Rios do Oeste, in the state of Paraná, Brazil.

\begin{tabular}{lcc}
\hline Scientific name & $\mathrm{NT}$ & $\mathrm{CT}$ \\
\hline Bidens pilosa $\mathrm{L}$. & $\mathrm{X}$ & $\mathrm{X}$ \\
Commelina benghalensis Wall. & $\mathrm{X}$ & $\mathrm{X}$ \\
Conyza canadenses (L.) Cronquist & $\mathrm{X}$ & $\mathrm{X}$ \\
Digitaria insularis (L.) Mez ex Ekman & $\mathrm{X}$ & $\mathrm{X}$ \\
Euphorbia heterophylla $\mathrm{L}$. & $\mathrm{X}$ & $\mathrm{X}$ \\
Ipomoea sp. & - & $\mathrm{X}$ \\
Leonurus sibiricus $\mathrm{L}$. & - & $\mathrm{X}$ \\
Phyllanthus niruri $\mathrm{L}$. & $\mathrm{X}$ & $\mathrm{X}$ \\
Richardia brasiliensis Gomez & $\mathrm{X}$ & $\mathrm{X}$ \\
Rumex obtusifolius L. & $\mathrm{X}$ & $\mathrm{X}$ \\
Sida sp. & $\mathrm{X}$ & $\mathrm{X}$ \\
Sonchus oleraceus $\mathrm{L}$. & $\mathrm{X}$ & $\mathrm{X}$ \\
Zea mays L. & $\mathrm{X}$ & $\mathrm{X}$ \\
\hline
\end{tabular}


showed a reduction in nitrogen accumulation of 82.6 and $81.3 \%$ in the conventional tillage and no-tillage systems, respectively.

Under conventional soil tillage, without weed competition, themaximum foliar nitrogen accumulation in the plants was $70.6 \%$ lower in the second crop cycle and $65.3 \%$ lower than that in the no-tillage system (Figure $3 \mathrm{~B}$ ). This is an indicative that the nutrient reserves of the roots in the first crop cycle may have resulted in a lower nutritional requirement of the plants in the next cycle (Gonzales et al., 2014). In addition, with weed competition, under conventional tillage and no-tillage, there was a reduction in maximum foliar nitrogen accumulation of 41.1 and $52.4 \%$, respectively.

The amount of phosphorus accumulated in the cassava leaves (Figure 4) was lower than that of nitrogen in both crop cycles (Figure 3), because phosphorus is extracted in small quantities by the plant (Pereira et al., 2012). However, under weed competition, the foliar accumulation of phosphorus was similar to that of

- $1^{\text {st }}$ cycle $-\mathrm{NT}: \mathrm{y}=0.3872\left(1 /\left(1+((\mathrm{x}-205.6885) / 41.0774)^{2}\right) ; \mathrm{R}^{2}=0.85^{* *}\right.$ $\circ 1^{\text {st }}$ cycle - CT: $\mathrm{y}=0.2719 \exp \left(-0.5((\mathrm{x}-159.0909) / 42.3807)^{2}\right) ; \mathrm{R}^{2}=0.94 * *$ $\nabla 2^{\text {nd }}$ cycle $-\mathrm{NT}: \mathrm{y}=0.3283\left(1 /\left(1+((\mathrm{x}-198.2934) / 41.5132)^{2}\right) ; \mathrm{R}^{2}=0.86^{*}\right.$

$\Delta 2^{\text {nd }}$ cycle - CT: $\mathrm{y}=0.2506 \exp \left(-0.5((\mathrm{x}-154.9708) / 46.5251)^{2}\right) ; \mathrm{R}^{2}=0.78^{* *}$

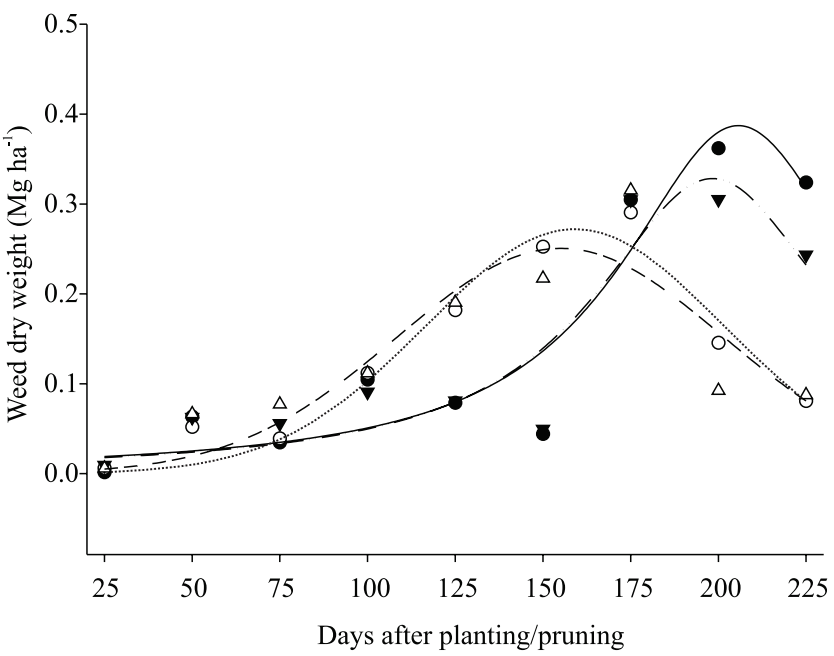

Figure 2. Regression analysis of weed dry weight accumulation on the basis of days after planting during the first cycle, from September 2014 to June 2015, and of days after pruning during the second cycle, from June 2015 to May 2016, of cassava (Manihot esculenta) plants grown in the conventional tillage (CT) and no-tillage (NT) systems in the municipality of Entre Rios do Oeste, in the state of Paraná, Brazil. * and **Significant at 5 and $1 \%$ probability of error, respectively. nitrogen in both cycles (Figure 4). The cassava plants began to accumulate phosphorus in their leaves after 75 DAP or DAPr, except when cultivated under no-tillage in the first cycle, i.e., at 69 DAP. After that period, the rate of accumulation remained low in comparison to that of the plants without competition until harvest.

- NT - competition: $\mathrm{y}=33.4695 /(1+\exp (-(\mathrm{x}-74.9299) / 1.1655)) ; \mathrm{R}^{2}=0.78^{* *}$

O NT - no competition: $\mathrm{y}=193.0553 /(1+\exp (-(\mathrm{x}-150.4748) / 29.2794)) ; \mathrm{R}^{2}=0.97 * *$

C C - competition: $\mathrm{y}=2.0108+40.2022 /(1+\exp (-(\mathrm{x}-75.7051) / 1.0958)) ; \mathrm{R}^{2}=0.88^{* *}$

$\triangle \mathrm{CT}$ - no competition: $\mathrm{y}=274.9938 /(1+\exp (-(\mathrm{x}-161.0738) / 31.7246)) ; \mathrm{R}^{2}=0.93 * *$

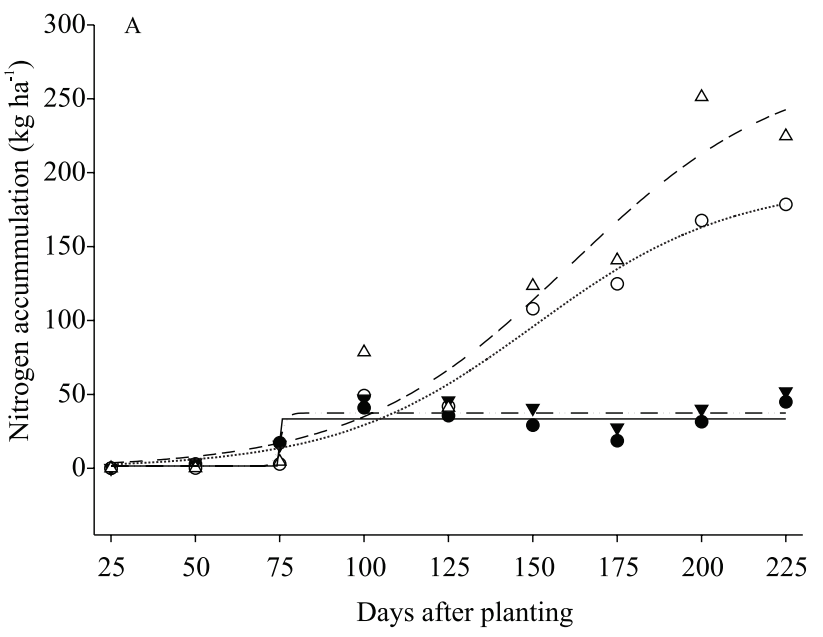

- NT- competition: $\mathrm{y}=0.6833+28.8838 /(1+\exp (-(\mathrm{x}-76.0175) / 1.0885)) ; \mathrm{R}^{2}=0.89^{* *}$ O NT - no competition: $\mathrm{y}=62.0580 /(1+\exp (-(\mathrm{x}-98.3870) / 9.2343)) ; \mathrm{R}^{2}=0.97 * *$

V CT - competition: $\mathrm{y}=0.5506+41.4453 /(1+\exp (-(\mathrm{x}-75.7067) / 0.5997)) ; \mathrm{R}^{2}=0.95^{* *}$

$\triangle \mathrm{CT}$ - no competition: $\mathrm{y}=0.1107+71.2533 /(1+\exp (-(\mathrm{x}-114.5745) / 15.3513)) ; \mathrm{R}^{2}=0.98^{* *}$

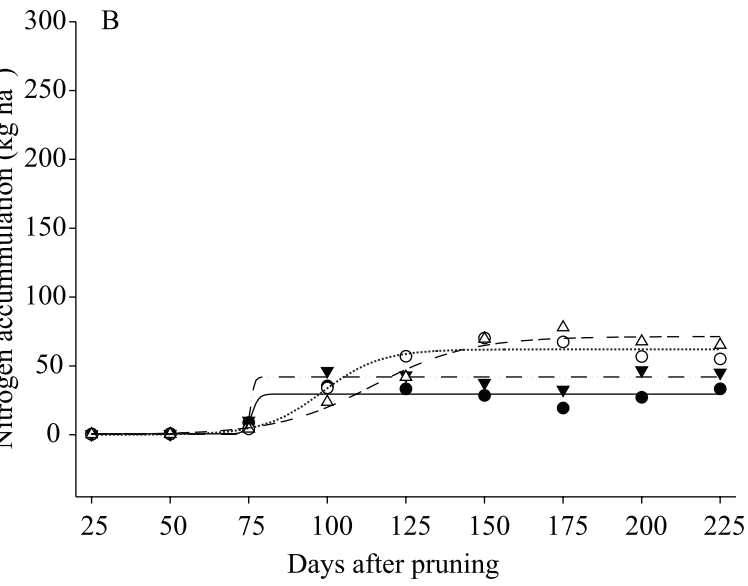

Figure 3. Regression analysis of foliar nitrogen accumulation in cassava (Manihot esculenta) plants at different periods of competition with weeds on the basis of days after planting in the first cycle, from September 2014 to June 2015 (A), and of days after pruning in the second cycle, from June 2015 to May 2016 (B), under conventional tillage (CT) and notillage (NT) in the municipality of Entre Rios do Oeste, in the state of Paraná, Brazil. * and **Significant at 5 and 1\% probability of error, respectively. 
In the first cycle, the maximum foliar phosphorus accumulation in the cassava plants competing with weeds was 65.7 and $85.3 \%$ lower than that of the plants

- NT - competition: $\mathrm{y}=0.6240 /(1+\exp (-(\mathrm{x}-69.3562) / 10.2662)) ; \mathrm{R}^{2}=0.77^{* *}$

O NT - no competition: $\mathrm{y}=5.8682 /(1+\exp (-(\mathrm{x}-186.3560) / 40.5761)) ; \mathrm{R}^{2}=0.97 * *$

$\checkmark \mathrm{CT}$ - competition $\mathrm{y}=1.2142 /(1+\exp (-(\mathrm{x}-75.7832) / 1.1481)) ; \mathrm{R}^{2}=0.71 *$

$\Delta \mathrm{CT}$ - no competition: $\mathrm{y}=-0.0745+3.9115 /(1+\exp (-(\mathrm{x}-146.9641) / 31.2308)) ; \mathrm{R}^{2}=0.90^{* *}$

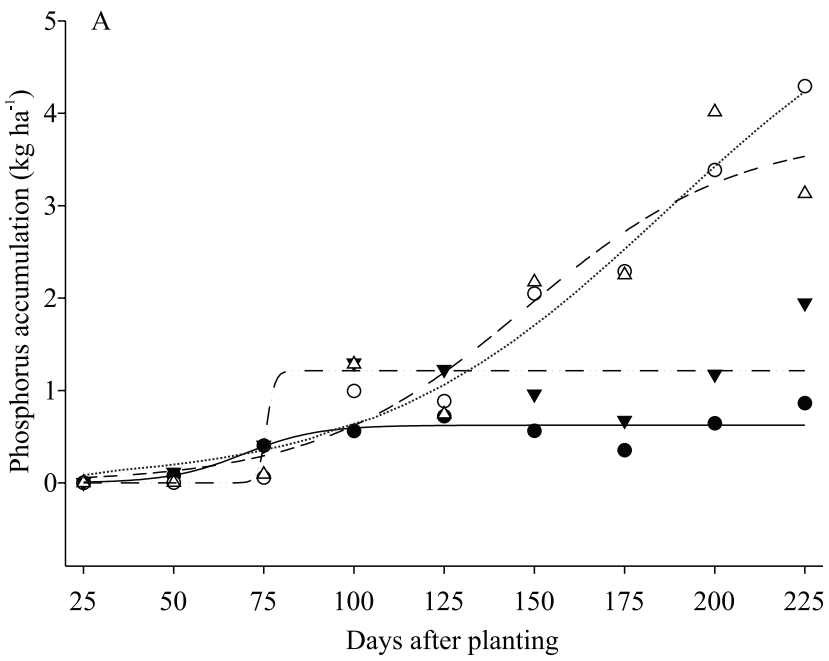

- NT - competition: $\mathrm{y}=0.0158+0.6042 /(1+\exp (-(\mathrm{x}-75.7443) / 1.1025)) ; \mathrm{R}^{2}=0.88^{* *}$

○ NT - no competition: $\mathrm{y}=1.3086 /(1+\exp (-(\mathrm{x}-103.4101) / 14.3783)) ; \mathrm{R}^{2}=0.99 * *$

$\nabla$ CT - competition: $\mathrm{y}=0.0133+0.9239 /(1+\exp (-(\mathrm{x}-75.9706) / 1.0336)) ; \mathrm{R}^{2}=0.93^{* *}$

$\Delta$ CT- no competition: $\mathrm{y}=1.6789 /(1+\exp (-(\mathrm{x}-116.0679) / 17.7485)) ; \mathrm{R}^{2}=0.99 * *$

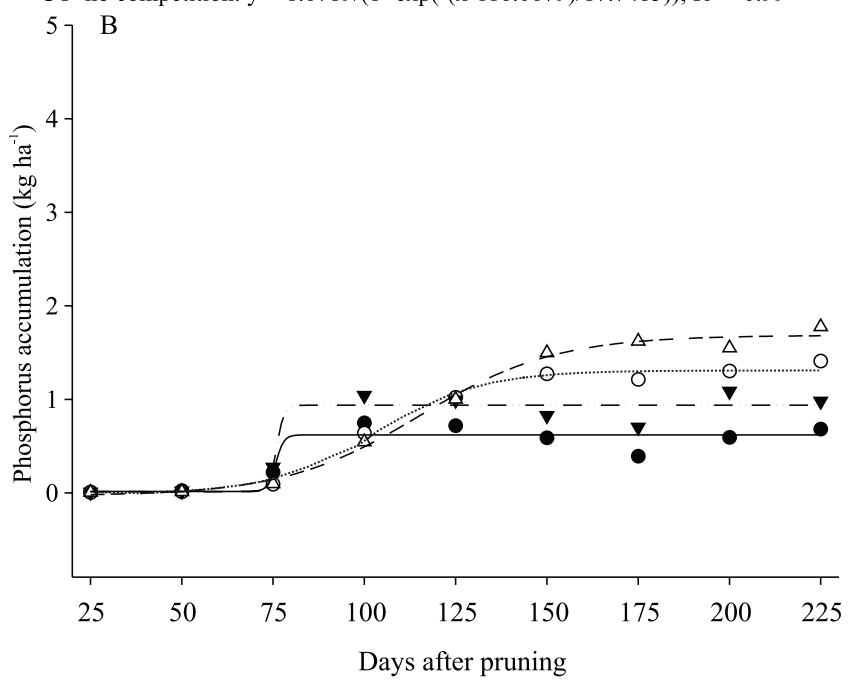

Figure 4. Regression analysis of foliar phosphorus accumulation in cassava (Manihot esculenta) plants at different periods of competition with weeds on the basis of days after planting in the first cycle, from September 2014 to June 2015 (A), and of days after pruning in the second cycle, from June 2015 to May 2016 (B), under conventional tillage (CT) and no-tillage (NT) in the municipality of Entre Rios do Oeste, in the state of Paraná, Brazil. * and **Significant at 5 and $1 \%$ probability of error, respectively. without competition under conventional tillage and no-tillage, respectively (Figure $4 \mathrm{~A}$ ). In addition, weed interference delayed by 71 and 117 days the period required for the cassava plants to accumulate, in their leaves, $50 \%$ of the phosphorus absorbed during the entire first cycle in the conventional tillage and notillage systems, respectively.

In the second cycle, the maximum foliar phosphorus accumulation in plants without weed competition and grown under conventional tillage and no-tillage, respectively, was 52.8 and $69.0 \%$ lower than that of the first cycle (Figure 4 B). Although the cassava plants had energy reserves and nutrients available in the tuberous roots after pruning, losses in foliar phosphorus accumulation could not be avoided due to weed interference during the new growth cycle of the crop. The crop-weed competition caused reductions in foliar phosphorus accumulation of 44.1 and $52.6 \%$ in the cassava plants in the conventional tillage and no-tillage systems, respectively.

Cassava root dry weight accumulation in the first cycle did not differ in either cultivation system, with or without weed interference (Figure 5). In cassava plants, the formation of the root system generally precedes that of the shoot in some cases, the buds of the stem can take up to 20 days to emerge from the soil after planting (Gonzales et al., 2014), a behavior that makes the species susceptible to the deleterious effects of weed interference (Silva et al., 2012). However, this did not occur in the present study, probably because there was a low weed infestation during the initial growth period of the crop (Figure 2). The crop-weed competition may have been tolerated by the cassava cultivar, which, consequently, allowed differentiating tuberous roots and the vegetative growth of the plants. However, further studies are needed to clarify the occurrence of a possible compensatory mechanism for root production, including roots of cassava plants with a low foliar accumulation of nitrogen and phosphorus due to weed competition.

The reductions in root dry weight accumulation caused by the competition with the weed community became more evident in the second crop cycle (Figure $5 \mathrm{~B})$. At the end of this cycle, there was a reduction in root dry weight accumulation of 15.8 and $11.2 \%$ in the cassava plants grown under conventional tillage and no-tillage, respectively. 
When comparing the cultivation systems of cassava, Pequeno et al. (2007) found that the root

- NT - competition: $\mathrm{y}=6.9395 /(1+\exp (-(\mathrm{x}-192.7640) / 31.5911)) ; \mathrm{R}^{2}=0.99 * *$ O NT - no competition: $\mathrm{y}=-0.0410+5.3241 /(1+\exp (-(\mathrm{x}-173.5414) / 28.5785)) ; \mathrm{R}^{2}=0.99^{* *}$ $\checkmark$ CT - competition: $\mathrm{y}=9.3420 /(1+\exp (-(\mathrm{x}-231.3670) / 45.0809)) ; \mathrm{R}^{2}=0.98^{* *}$ $\Delta$ CT- no competition: $\mathrm{y}=0.1392+4.2074 /(1+\exp (-(\mathrm{x}-164.0921) / 17.9533)) ; \mathrm{R}^{2}=0.96 * *$

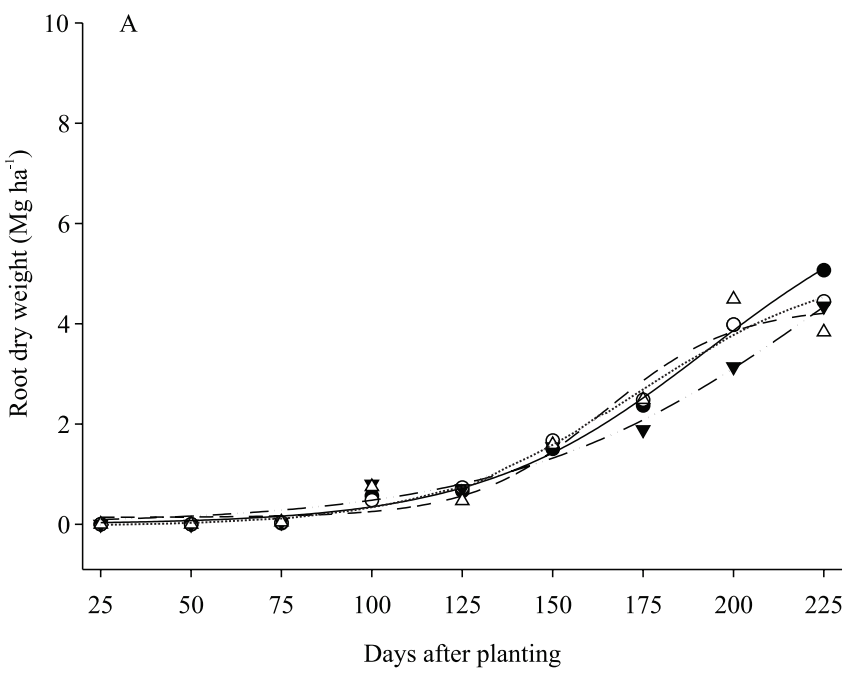

- NT - competition: $\mathrm{y}=5.3145+0.0074 x ; \mathrm{R}^{2}=0.94 * *$

○ NT - no competition: $\mathrm{y}=6.7820+0.0048 x ; \mathrm{R}^{2}=0.64 * *$

V CT- competition: $\mathrm{y}=6.0076+0.0069 \mathrm{x} ; \mathrm{R}^{2}=0.96^{* *}$

$\triangle$ CT - no competition: $\mathrm{y}=6.5289+0.0293 \mathrm{x}-0.000081796 \mathrm{x}^{2} ; \mathrm{R}^{2}=0.94 * *$

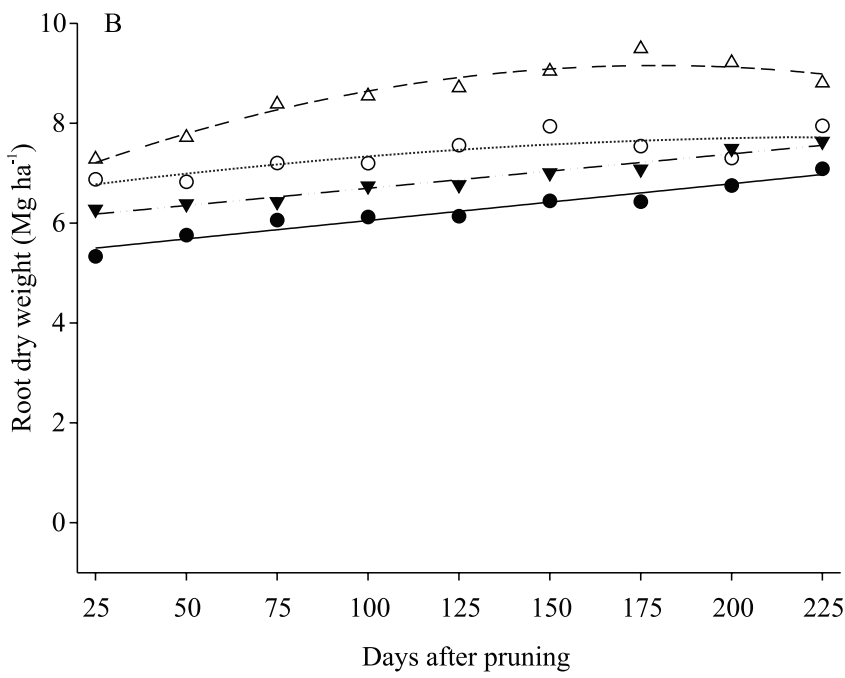

Figure 5. Regression analysis of root dry weight of cassava (Manihot esculenta) plants at harvest, at different periods of competition with weeds, on the basis of days after planting in the first cycle, from September 2014 to June 2015 (A), and of days after pruning in the second cycle, from June 2015 to May 2016 (B), under conventional tillage (CT) and notillage (NT) in the municipality of Entre Rios do Oeste, in the state of Paraná, Brazil. * and **Significant at 5 and 1\% probability of error, respectively. production in the first cycle was $26.2 \%$ higher in conventional tillage. A possible explanation is that the turnover of the superficial soil layers, under this type of tillage, increases total porosity and groundwater flow and air storage capacity, favoring root development and nutrient absorption (Zhang et al., 2018). However, Gabriel Filho et al. (2000) did not observe any differences in the root yield of cassava grown in the conventional tillage and notillage systems with different cover crops. Contrarily, Fasinmirin \& Reichert (2011) reported that, although there is a greater resistance to root penetration in soil under no-tillage, cassava can be successfully planted in this system, with benefits related to nutrient cycling, reduction of thermal amplitude, and preservation of soil physical properties when compared with conventional tillage.

The reduction in the accumulation of nutrients in the leaves of cassava plants has proven to be an important weed interference mechanism, regardless of the tillage system being used. The deleterious effects on nutrient absorption started from 70 to 75 DAP or DAPr, coinciding with the period of a higher growth rate and differentiation of tuberous roots (first cycle) or of energy expenditure for the resumption of starch storage in the roots after plant pruning (second cycle). This period also coincides with the critical period of interference prevention, defined by Biffe et al. (2010) as being from 18 to 100 DAP for the first cycle of cassava. However, there are no data in the literature on this period for the second cycle, which indicates the need for further studies.

In practice, fertilizer application during the period the crop showed the greatest susceptibility in conditions of low infestation or after weed control can be an important strategy to avoid or compensate for the damage to plant development and crop yield caused by the competition of overgrown weeds. It can also ensure a better nutritional quality of the plant shoot for animal and even human consumption (Latif \& Müller, 2015). In general, the fertilization of cassava is expected to promote an increase in plant shoot, the fast closing of the crown, and, consequently, the shading of weed species (Soares et al., 2019).

Regardless of the type of management adopted, the importance of weed control is evident, since competing vegetation reduces foliar nutrient accumulation and interferes in the development of cassava roots. 


\section{Conclusions}

1. The competition of the weed community with cassava (Manihot esculenta) plants reduces the foliar accumulation of nitrogen and phosphorus, both in the conventional tillage and no-tillage systems, especially in the second crop cycle.

2. The dry weight accumulation of cassava roots is not affected by weed competition in the first cycle, despite reductions in foliar nutrient accumulation, but is reduced by it in the no-tillage system in the second cycle.

\section{Acknowledgments}

To Coordenação de Aperfeiçoamento de Pessoal de Nível Superior (Capes), for partially funding this study (Finance Code 001); and to Conselho Nacional de Desenvolvimento Científico e Tecnológico (CNPq), for scholarships.

\section{References}

ACHARYA, B.S.; DODLA, S.; GASTON, L.A.; DARAPUNENI, M.; WANG, J.J.; SEPAT, S.; BOHARA, H. Winter cover crops effect on soil moisture and soybean growth and yield under different tillage systems. Soil and Tillage Research, v.195, art.104430, 2019. DOI: https://doi.org/10.1016/j.still.2019.104430.

ALVARES, C.A.; STAPE, J.L.; SENTELHAS, P.C.; GONÇALVES, J.L. de M.; SPAROVEK, G. Köppen's climate classification map for Brazil. Meteorologische Zeitschrift, v.22, p.711-728, 2013. DOI: https://doi.org/10.1127/09412948/2013/0507.

BIFFE, D.F.; CONSTANTIN, J.; OLIVEIRA JR., R.S.; FRANCHINI, L.H.M.; RIOS, F.A.; BLAINSKI, E.; ARANTES, J.G.Z.; ALONSO, D.G.; CAVALIERI, S.D. Período de interferência de plantas daninhas em mandioca (Manihot esculenta) no noroeste do Paraná. Planta Daninha, v.28, p.471-478, 2010. DOI: https://doi.org/10.1590/S0100-83582010000300003.

CARVALHO, L.B.; BIANCO, S.; GUZZO, C.D. Interferência de Euphorbia heterophylla no crescimento e acúmulo de macronutrientes da soja. Planta Daninha, v.28, p.33-39, 2010. DOI: https://doi.org/10.1590/S0100-83582010000100004.

FAO. Food and Agriculture Organization of the United Nations. Protecting cassava, a neglected crop, from pests and diseases. 2019. Available at: <http://www.fao.org/3/ca7117en/CA7117EN. pdf>. Accessed on: Sept. 242020.

FASINMIRIN, J.T.; REICHERT, J.M. Conservation tillage for cassava (Manihot esculenta Crantz) production in the tropics. Soil and Tillage Research, v.113, p.1-10, 2011. DOI: https://doi.org/10.1016/j.still.2011.01.008.
FERREIRA, D.F. Sisvar: a computer analysis system to fixed effects split plot type designs. Revista Brasileira de Biometria, v.37, p.529-535, 2019. DOI: https://doi.org/10.28951/rbb.v37i4.450.

FIDALSKI, J. Respostas da mandioca à adubação NPK e calagem em solos arenosos do noroeste do Paraná. Pesquisa Agropecuária Brasileira, v.34, p.1353-1359, 1999. DOI: https://doi.org/10.1590/ s0100-204x1999000800005.

FIGUEIREDO, P.G.; BICUDO, S.J.; CHEN, S.; FERNANDES, A.M.; TANAMATI, F.Y.; DJABOU-FONDJO, A.S.M. Effects of tillage options on soil physical properties and cassava-dry-matter partitioning. Field Crops Research, v.204, p.191-198, 2017. DOI: https://doi.org/10.1016/j.fcr.2016.11.012.

GABRIEL FILHO, A.; PESSOA, A.C. dos S.; STROHHAECKER, L.; HELMICH, J.J. Preparo convencional e cultivo mínimo do solo na cultura da mandioca em condições de adubação verde com ervilhaca e aveia preta. Ciência Rural, v.30, p.953-957, 2000. DOI: https://doi.org/10.1590/S0103-84782000000600005.

GONZALES, P.F.; BICUDO, S.J.; MORAES-DALLAQUA, M.A.; TANAMATI, F.Y.; AGUIAR, E.B. Componentes de produção e morfologia de raízes de mandioca sob diferentes preparos do solo. Bragantia, v.73, p.357-364, 2014. DOI: https://doi.org/10.1590/1678-4499.0150.

GUIMARÃES, D.G.; AMARAL, C.L.F.; VIANA, A.E.S.; PÚBLIO JÚNIOR, E.; SANTOS, V. da S.; LOPES, S.C.; FOGAÇA, J.J.N.L. Estimativas de parâmetros genéticos em genótipos de mandioca cultivados em solos de baixa fertilidade natural. Cultura Agronômica, v.28, p.280-298, 2019. DOI: https://doi.org/10.32929/2446-8355.2019v28n3p280-298.

JOHANNS, O.; CONTIERO, R.L. Efeitos de diferentes períodos de controle e convivência de plantas daninhas com a cultura da mandioca. Revista Ciência Agronômica, v.37, p.326-331, 2006.

KANG, L.; LIANG, Q.-Y.; JIANG, Q.; YAO, Y.-H.; DONG, M.-M.; HE, B.; GU, M.-H. Screening of diverse cassava genotypes based on nitrogen uptake efficiency and yield. Journal of Integrative Agriculture, v.19, p.965-974, 2020. DOI: https://doi.org/10.1016/S2095-3119(19)62746-2.

LANA, M. do C.; FRANDOLOSO, J.F.; FEY, R.; RICHART, A.; FONTANIVA, S. Análise química de solo e de tecido vegetal. 2.ed. rev. Cascavel: Edunioeste, 2016. 153p.

LATIF, S.; MÜLLER, J. Potential of cassava leaves in human nutrition: a review. Trends in Food Science and Technology, v.44, p.147-158, 2015. DOI: https://doi.org/10.1016/j.tifs.2015.04.006.

LORENZI, H. (Coord.). Manual de identificação e controle de plantas daninhas: plantio direto e convencional. 7.ed. Nova Odessa: Plantarum, 2014. 384p.

MOREIRA, A.; MOTTA, A.C.V; COSTA, A.; MUNIZ, A.S.; CASSOL, L.C.; ZANÃO JÚNIOR, L.A.; BATISTA, M.A.; MÜLlER, M.M.L.; HAGER, N.; PAUlETTI, V. (Ed.). Manual de adubação e calagem para o Estado do Paraná. Curitiba: SBCS, Núcleo Estadual do Paraná, 2017. 482p.

MUNYAHALI, W.; PYPERS, P.; SWENNEN, R.; WALANGULULU, J.; VANLAUWE, B.; MERCKX, R. Responses of cassava growth and yield to leaf harvesting frequency and NPK fertilizer in South Kivu, Democratic Republic 
of Congo. Field Crops Research, v.214, p.194-201, 2017. DOI: https://doi.org/10.1016/j.fcr.2017.09.018.

OTSUBO, A.A.; BRITO, O.R.; PASSOS, D.P.; ARAUJO, H.S. de; MERCANTE, F.M.; OTSUBO, V.H.N. Formas de preparo de solo e controle de plantas daninhas nos fatores agronômicos e de produção da mandioca. Semina: Ciências Agrárias, v.33, p.2241-2246, 2012. DOI: https://doi.org/10.5433/1679$0359.2012 \mathrm{v} 33 \mathrm{n} 6 \mathrm{p} 2241$.

PEQUENO, M.G.; VIDIGAL FILHO, P.S.; TORMENA, C.; KVITSCHAL, M.V; MANZOTTI, M. Efeito do sistema de preparo do solo sobre características agronômicas da mandioca (Manihot esculenta Crantz). Revista Brasileira de Engenharia Agrícola e Ambiental, v.11, p.476-481, 2007. DOI: https://doi.org/10.1590/S1415-43662007000500005.

PEREIRA, G.A.M.; LEMOS, V.T.; SANTOS, J.B. dos; FERREIRA, E.A.; SILVA, D.V.; OLIVEIRA, M.C. de; MENEZES, C.W.G. de. Crescimento da mandioca e plantas daninhas em resposta à adubação fosfatada. Revista Ceres, v.59, p.716-722, 2012. DOI: https://doi.org/10.1590/S0034-737X2012000500019.

SANTOS, H.G. dos; JACOMINE, P.K.T.; ANJOS, L.H.C. dos; OLIVEIRA, V.Á. de; LUMBRERAS, J.F.; COELHO, M.R.; ALMEIDA, J.A. de; ARAÚJO FILHO, J.C. de; OLIVEIRA, J.B. de; CUNHA, T.J.F. Sistema brasileiro de classificação de solos. 5.ed. rev. e ampl. Brasília: Embrapa, 2018. 356p.

SILVA, D.V.; SANTOS, J.B.; FERREIRA, E.A.; SILVA, A.A.; FRANÇA, A.C.; SEDIYAMA, T. Manejo de plantas daninhas na cultura da mandioca. Planta Daninha, v.30, p.901-910, 2012. DOI: https://doi.org/10.1590/S0100-83582012000400025.

SOARES, M.R.S.; SÃO JOSÉ, A.R.; NUNES, R.T.C.; SILVA, R. de A.; CAETANO, A.P.O.; OLIVEIRA, D.S. de; NOLASCO, C. de A.; RAMPAZZO, M.C. Períodos de interferência de plantas infestantes na cultura da mandioca, submetida ou não à adubação NPK, em Vitória da Conquista-Ba. Revista de Ciências Agrárias, v.42, p.237-247, 2019. DOI: https://doi.org/10.19084/RCA18166.

SYSTAT SOFTWARE INC. SigmaPlot for windows version 12.0. San Jose, 2011.

TAKAHASHI, M.; GONÇALO, S. A cultura da mandioca. Paranavaí: Indemil, 2001. 88p.

ZHANG, Y.; WANG, S.; WANG, H.; NING, F.; ZHANG, Y.; DONG, Z.; WEN, P.; WANG, R.; WANG, X.; LI, J. The effects of rotating conservation tillage with conventional tillage on soil properties and grain yields in winter wheat-spring maize rotations. Agricultural and Forest Meteorology, v.263, p.107117, 2018. DOI: https://doi.org/10.1016/j.agrformet.2018.08.012. 